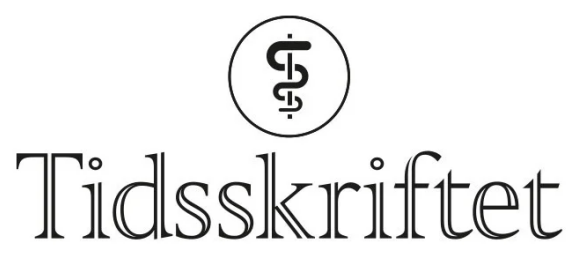

DEN NORSKE LEGEFORENING

\title{
Hva er optimal folatstatus?
}

\author{
FRA LABORATORIET
}

\section{ANNE-LISE BJØRKE-MONSEN}

anne-lise.bjorke.monsen@helse-bergen.no

Anne-Lise Bjørke-Monsen er spesialist i barnesykdommer og i medisinsk biokjemi, overlege ved Avdeling for medisinsk biokjemi og farmakologi ved Haukeland universitetssjukehus og førsteamanuensis ved Klinisk institutt 2 ved Universitetet i Bergen. Hun er styremedlem i Norsk selskap for medisinsk biokjemi.

Forfatteren har fylt ut ICMJE-skjemaet og oppgir ingen interessekonflikter.

\section{RENATE RENSTR ØM}

Renate Renstrøm er lege i spesialisering ved Avdeling for medisinsk biokjemi og farmakologi ved Haukeland universitetssjukehus.

Forfatteren har fylt ut ICMJE-skjemaet og oppgir ingen interessekonflikter.

\section{Folat er essensielt for DNA-syntese og cellevekst. Mangel er spesielt uheldig i svangerskapet og er assosiert med økt risiko for misdannelser hos fosteret.}

Folat finnes det mye av i grønnsaker og frukt, men vitaminet er ustabilt, og 50-80\% forsvinner ved koking. I USA og noen andre land anrikes frokostblandinger og mel med syntetisk folat, folinsyre, noe som reflekteres i befolkningens folatstatus. Median konsentrasjon av serumfolat hos amerikanske kvinner i fertil alder er 39,o nmol/l (1). Tilsvarende verdi hos norske kvinner i samme aldersgruppe er 13,8 $\mathrm{nmol} / \mathrm{l}$ (egne data).

Behovet for folat $\emptyset$ ker i vekstperioder og ved svangerskap og amming. Maternell folatmangel er assosiert med $ø \mathrm{kt}$ risiko for misdannelser hos fosteret, og det er anbefalt at kvinner tar $400 \mu g$ folat daglig fra én måned før befruktning til og med første trimester for å redusere risikoen for nevralrørsdefekt hos fosteret. I land der man har innført folinsyreanriking, er forekomsten av nevralrørsdefekter redusert (2 $\underline{2}$. En slik reduksjon er ikke observert i Europa (3). Det har vært diskutert om folinsyreanriking kan øke risikoen for kreft, men det er ikke funnet noen endring i kreftprevalens i land som har innført dette (4).

Ekstra inntak av folat er ofte nødvendig gjennom hele svangerskapet og i ammeperioden for å unngå maternell mangel (5). Folatkonsentrasjonen i morsmelk holder seg høy gjennom ammeperioden, og folatkonsentrasjonen i serum er høy første og andre leveår. Folatmangel er sjelden hos småbarn (ㅁ). 
Ved utredning av folatstatus er det tilstrekkelig å måle serumfolat. Konsentrasjonen i serum påvirkes raskt ved endret inntak eller opptak, noe som gjør serumfolat velegnet som markør for ernæringsstatus og tarmfunksjon.

Folat er sammen med kobalamin nødvendig for å remetylere homocystein til metionin, og mangel på ett eller begge av disse vitaminene vil øke homocysteinkonsentrasjonen og redusere metioninkonsentrasjonen. Hos eldre barn og voksne er konsentrasjonen av homocystein hovedsakelig en folatmarkør, og den begynner å stige når konsentrasjonen av serumfolat faller under $25-27 \mathrm{nmol} / \mathrm{l}$ (figur 1), som tegn på en ikke-optimal intracellulær folatstatus. Et daglig inntak av 300-400 $\mu$ g folat er hos voksne assosiert med en stabil konsentrasjon av homocystein i plasma.

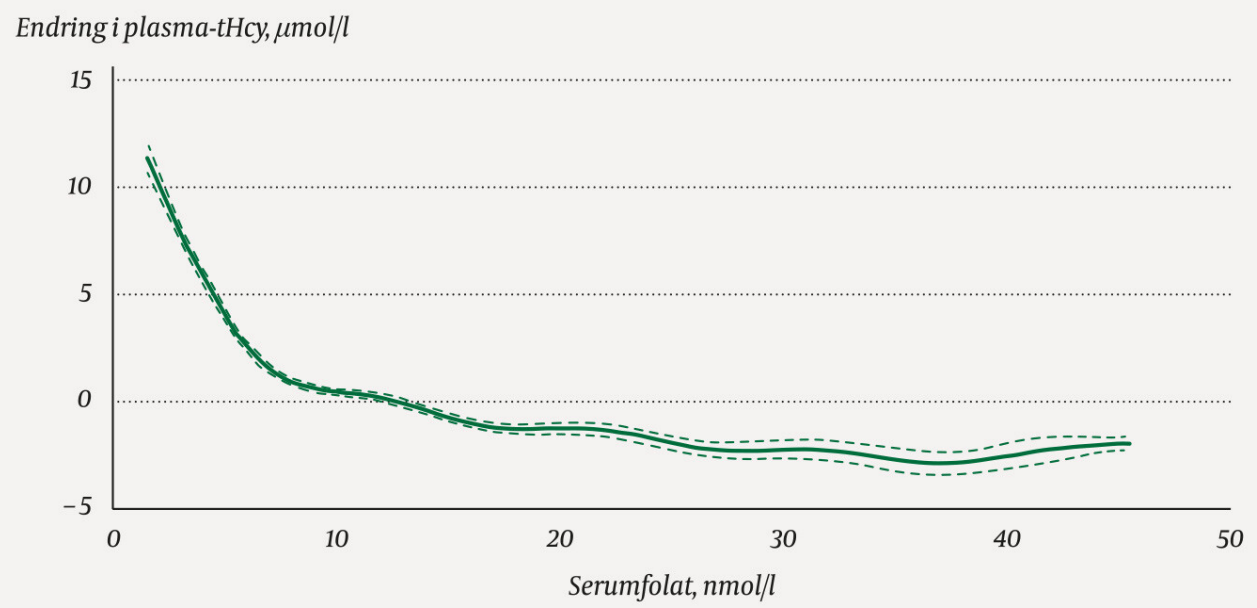

Figur 1 Endring i konsentrasjon av totalhomocystein (tHcy) i plasma i forhold til folat $\mathrm{i}$ serum hos voksne over 16 år med glomerulær filtrasjonshastighet (GFR) $>60 \mathrm{ml} / \mathrm{min} / 1,73$ m2. Verdiene på y-aksen angir endring fra gjennomsnittet for tHcy. De stiplede linjene angir $95 \%$ konfidensintervall. Figuren er basert på pasientdata $(n=12988)$ fra Avdeling for medisinsk biokjemi og farmakologi ved Haukeland universitetssjukehus.

Ved uttalt folatmangel kan konsentrasjonen av plasmahomocystein øke til opp mot 40-50 $\mu \mathrm{mol} / \mathrm{l}$. Individer som er homozygote for C677T-polymorfismen i MTHFR-genet (metylentetrahydrofolatreduktase) (prevalens 5-15\%), kan få høyere homocysteinkonsentrasjon (opp mot $100 \mu \mathrm{mol} / \mathrm{l}$ ) ved lave serumfolatverdier, og en konsentrasjon $>15 \mathrm{nmol} / \mathrm{l}$ er anbefalt hos disse pasientene (7.).

Verdens helseorganisasjon anbefaler en aksjonsgrense for folatmangel på $<10 \mathrm{nmol} / \mathrm{l}(\underline{8})$. Hos kvinner i fertil alder bør konsentrasjonen av serumfolat være $>25,5 \mathrm{nmol} / \mathrm{l}$ for å forebygge misdannelser hos fosteret (9.). Dette tilsvarer den konsentrasjonen av erytrocyttfolat som i studier er vist å gi økt genomisk stabilitet (므) og en stabilt lav konsentrasjon av plasmahomocystein hos voksne (figur 1).

\section{LITTERATUR}

1. Nguyen B, Weiss P, Beydoun $\mathrm{H}$ et al. Association between blood folate concentrations and depression in reproductive aged U.S. women, NHANES (2011-2012). J Affect Disord 2017; 223: 209-17. [PubMed][CrossRef]

2. De-Regil LM, Peña-Rosas JP, Fernández-Gaxiola AC et al. Effects and safety of periconceptional oral folate supplementation for preventing birth defects. Cochrane Database Syst Rev 2015; nr. 12: CDoo7950. [PubMed][CrossRef]

3. Khoshnood B, Loane M, de Walle $\mathrm{H}$ et al. Long term trends in prevalence of neural tube defects in Europe: population based study. BMJ 2015; 351: h5949. [PubMed][CrossRef]

4. Vollset SE, Clarke R, Lewington $S$ et al. Effects of folic acid supplementation on overall and sitespecific cancer incidence during the randomised trials: meta-analyses of data on 50,000 individuals. Lancet 2013; 381:1029-36. [PubMed][CrossRef] 
5. Allen LH. Causes of vitamin B12 and folate deficiency. Food Nutr Bull 2008; 29 (Suppl): S2O-34, discussion S35-7. [PubMed][CrossRef]

6. Monsen AL, Refsum H, Markestad T et al. Cobalamin status and its biochemical markers methylmalonic acid and homocysteine in different age groups from 4 days to 19 years. Clin Chem 2003; 49: 2067-75. [PubMed][CrossRef]

7. Huang X, Qin X, Yang W et al. MTHFR gene and serum folate interaction on serum homocysteine lowering: Prospect for precision folic acid treatment. Arterioscler Thromb Vasc Biol 2018; 38: 679-85. [PubMed][CrossRef]

8. de Benoist B. Conclusions of a WHO Technical Consultation on folate and vitamin B12 deficiencies. Food Nutr Bull 2008; 29 (Suppl): S238-44. [PubMed][CrossRef]

9. Chen MY, Rose CE, Qi YP et al. Defining the plasma folate concentration associated with the red blood cell folate concentration threshold for optimal neural tube defects prevention: a populationbased, randomized trial of folic acid supplementation. Am J Clin Nutr 2019; 109:1452-61. [PubMed] [CrossRef]

10. Fenech M. Folate (vitamin B9) and vitamin B12 and their function in the maintenance of nuclear and mitochondrial genome integrity. Mutat Res 2012; 733: 21-33. [PubMed][CrossRef]

Publisert: 4. mai 2020. Tidsskr Nor Legeforen. DOI:10.4045/tidsskr.19.0588

(C) Tidsskrift for Den norske legeforening 2023. Lastet ned fra tidsskriftet.no 26. april 2023. 